\title{
Protein Wnt-10b
}

National Cancer Institute

\section{Source}

National Cancer Institute. Protein Wnt-10b. NCI Thesaurus. Code C21249.

Protein Wnt-10b (389 aa, 43 kDa) is encoded by the human WNT10B gene. This protein plays a role in signaling that modulates pluripotency and cell fate. 